Jurnal Akuntansi dan Manajemen

Vol. 11, No. 2, 2016, Hal. 1-25

\title{
Analisis Perbandingan Prediksi Kebangkrutan Bank Syariah Dan Bank Konvensional Menggunakan Altman's EM Z- Score Model
}

\author{
Agnes Anggun Minati1), Gustati'2), Hidayatul Ihsan ${ }^{3)}$ \\ Jurusan Akuntansi, Politeknik Negeri Padang
}

Email: agnes.anggun@gmail.com ${ }^{1)}$ gustati1602@yahoo.com ${ }^{2)}$ ihsanm@gmail.com ${ }^{3)}$

\begin{abstract}
The development of Islamic banks in Indonesia increasingly shows that Islamic banks are ready to become competitors for conventional banks. Islamic banks that use margin systems or profit sharing whereas conventional banks use interest systems give rise to different expectations. It is possible to have a difference in terms of bankruptcy prediction using the Altman EM Z-Score Model ratio. The Altman EM ZScore Model is a modification of the Altman ratio in 2002 that is used for non-manufacturing companies and has not gone public. This final project aims to analyze the comparison of predictions of bankruptcy of conventional Islamic banks and banks using Altman's EM Z-Score Model for the period 2012-2014. This type of research is descriptive comparative research. The sample used was 11 Islamic Commercial Banks and 23 Conventional Commercial Banks selected using the purposive sampling method. Data analysis techniques use different tests in whitney SPSS version 20. Based on the results of Z " - Score shows that Indonesian banks are in a healthy state, but Islamic banks are more stable than conventional banks, while the results of whitney test show there are differences in working capital to total assets, retained earnings to total assets, EBIT to total assets, but there is no difference in the book value of equity to total liabilities of Islamic banks and conventional banks.
\end{abstract}

Keywords: Islamic banks, conventional banks, Altman's EM Z-Score Model rasio

\begin{abstract}
ABSTRAK
Perkembangan bank syariah di Indonesia semakin menunjukkan bahwa bank syariah siap menjadi kompetitor bagi bank konvensional. Bank syariah yang menggunakan sistem margin atau bagi hasil sedangkan bank konvensional menggunakan sistem bunga menimbulkan ekspektasi yang berbeda. Hal ini dimungkinkan mempunyai perbedaan dalam hal prediksi kebangkrutan menggunakan rasio Altman EM Z- Score Model. Altman EM Z-Score Model merupakan modifikasi rasio Altman tahun 2002 yang digunakan untuk perusahaan nonmanufaktur dan belum go public. Tugas akhir ini bertujuan untuk menganalisis perbandingan prediksi kebangkrutan bank syariah dan bank konvensional menggunakan Altman's EM Z- Score Model periode 2012-2014. Jenis penelitian ini adalah penelitian deskriptif komparatif. Sampel yang digunakan adalah 11 Bank Umum Syariah dan 23 Bank Umum Konvensional yang dipilih menggunakan metode purposive sampling. Teknik analisis data menggunakan uji beda u mann whitney SPSS versi 20. Berdasarkan hasil Z"Score menunjukkan bahwa bank Indonesia berada dalam keadaan sehat, namun bank syariah lebih stabil dibandingkan bank konvensional, sedangkan dari hasil uji u mann whitney menunjukkan terdapat perbedaan working capital to total assets, retained earnings to total assets, EBIT to total assets, namun tidak terdapat perbedaan book value of equity to total liabilities bank syariah dan bank konvensional.
\end{abstract}

Kata kunci: Bank syariah, bank konvensional, rasio kebangkrtuan Altman's EM Z-Score Model.

\section{PENDAHULUAN}

Perbankan di Indonesia telah berkembang dengan pesat melalui dual banking system, yaitu sistem perbankan konvensional dan sistem perbankan berbasis syariah. Persentase pertumbuhan bank syariah lebih besar dibanding bank konvensional. Menurut data Bank Indonesia, lima tahun terakhir pertumbuhan bank syariah rata-rata $38-40 \%$ per tahun. Dengan pertumbuhan besar bukan tidak 
mungkin pangsa pasar bank syariah semakin besar. Salah satu kelebihan bank syariah dibanding bank konvensional adalah perhatian yang lebih besar kepada sektor mikro (Sindo, 2014). Jika bank syariah terus berkembang lebih baik kedepannya, bukan tidak mungkin semua sektor perbankan di Indonesia menjadi syariah karena mayoritas masyarakat Indonesia beragama Islam. Maka dari itu, perbankan konvensional harus mampu terus bersaing dengan produk yang lebih inovatif agar kondisi keuangan perbankan tetap terjaga dan tidak diragukan.

Dunia perbankan perlu memberikan perhatian khusus terhadap gejolak ekonomi yang akan dihadapi di masa mendatang. Terlebih lagi, dunia perbankan pernah menghadapi masa-masa sulit, dan bukan tidak mungkin hal tersebut terulang kapan saja. Krisis moneter tahun 1997 yang mengoncang perekonomian Indonesia dan terjadi kembali tahun 2008 telah memberikan dampak terhadap perekonomian secara global, khususnya dunia perbankan. Menurut Humas Bank Indonesia (2010), tingkat keseriusan dan kegentingan kondisi perbankan terlihat ketika Rapat Dewan Gubernur BI pada tanggal 29 Oktober 2008 memutuskan untuk mengaktifkan Protokol Manajemen Krisis (Crisis Management Protocol). Dihidupkannya mekanisme Crisis Management Protocol memberi sinyal kepada publik bahwa situasi memang genting. Laporan data dan informasi ekonomi, moneter dan perbankan dimonitor secara intensif. Berbagai isu-isu sensitif terhadap perbankan pun terus dipantau, guna menghadapi gejolak ekonomi moneter dan indeks kestabilan keuangan.

Kasus Bank Century merupakan salah satu contoh kategori bank gagal, karena sempat masuk sebagai bank dalam pengawasan khusus oleh BI tahun 2008. Saat itu, kasus tersebut menjadi trending topic di kalangan masyarakat Indonesia. Oleh karena itu, dilakukanlah penyelamatan terhadap likuiditas Bank Century yang tujuan utamanya untuk mempertahankan kepercayaan nasabah pada perbankan nasional. Maka diperlukan suatu analisis/prediksi kebangkrutan perusahaan yang didapatkan melalui rasio-rasio keuangan yang bisa menjadi alarm peringatan terhadap pihak manajemen bank. Model prediksi kebangkrutan tersebut juga dibutuhkan oleh stakeholder perusahaan seperti investor, kreditur dan nasabah sebagai dasar pengambilan keputusan yang tepat. Faktor modal dan risiko keuangan ditengarai mempunyai peran penting dalam menjelaskan fenomena kepailitan bank tersebut. Dengan terdeteksinya lebih awal kondisi perbankan maka sangat memungkinkan bagi bank tersebut melakukan langkah-langkah antisipatif guna mencegah agar krisis keuangan segera tertangani.

Sejauh ini, tidak banyak peneliti Indonesia menggunakan $Z$ ''-Score model ini sebagai alat untuk prediksi kebangkrutan terutama untuk perusahaan non manufaktur seperti perbankan. Kebanyakan peneliti sebelumnya menggunakan model Altman original atau Z-Score dan rasio keuangan lainnya untuk meneliti kebangkrutan perusahaan non manufaktur. Padahal, model Altman Z-Score original adalah model prediksi yang digunakan pertama kali pada perusahaan manufaktur kimia. Salah satu peneliti yang menggunakan Z"-Sore adalah Othman (2011) dimana ia membandingkan prediksi kebangkrutan bank syariah dan bank konvensional di Malaysia. Akan tetapi belum ada peneliti serupa dilakukan di Indonesia. Oleh karena itu, penelitian ini bertujuan untuk memprediksi kebangkrutan bank syariah dan bank konvensional di Indonesia periode 2012-2014 dengan menggunakan model Z"-Score. 


\section{TINJAUAN PUSTAKA DAN HIPOTESIS \\ Tinjauan Pustaka \\ Kebangkrutan}

Kebangkrutan diartikan sebagai kegagalan perusahaan dalam menjalankan operasi perusahaan untuk menghasilkan laba (Purnamawati, 2012). Kebangkrutan sering disebut likuidasi perusahaan atau penutupan perusahaan atau insolvabilitas. Kebangkrutan sebagai kegagalan didefinisikan dalam beberapa arti (Mertin, et al., 1995, dalam Umar dan Andi, 2005), yaitu: Pertama, kegagalan ekonomi (ecomonic failure), berarti perusahaan kehilangan uang atau pendapatan perusahaan tidak menutup biayanya sendiri. Kegagalan terjadi bila arus kas sebenarnya dari perusahaan jatuh di bawah arus kas yang diharapkan. Dimana tingkat pendapatan atas biaya historis investasinya lebih kecil daripada biaya modal perusahaan.

Kedua, kegagalan keuangan (financial failure), diartikan sebagai insolvensi yang dibedakan dalam dua bentuk, yaitu: (a) insolvensi teknis (technical insolvency), dianggap gagal jika tidak dapat memenuhi kewajiban pada saat jatuh tempo walaupun total aktiva melebihi total utang, atau terjadi suatu perusahaan gagal memenuhi salah satu/lebih kondisi dalam ketentuan hutangnya seperti rasio aktiva lancar terhadap utang lancar yang ditetapkan atau rasio kekayaan bersih terhadap total aktiva yang disyaratkan. Selain itu, bisa terjadi bila arus kas tidak cukup untuk memenuhi pembayaran bunga atau pembayaran kembali pokok pada tanggal tertentu. (b) insolvensi dalam pengertian kebangkrutan. Didefenisikan dalam ukuran sebagai kekayaan bersih negatif dalam neraca konvensional atau nilai sekarang dari arus kas yang diharapkan lebih kecil dari kewajiban. Sering disebut likuidasi perusahaan atau penutupan perusahaan atau insolvabilitas. Likuiditas/pembubaran perusahaan senantiasa berakibat penutupan perusahaan, tetapi likuiditas tidak selalu berarti perusahaan bangkrut.

Tanda-tanda terjadinya kebangkrutan perusahaan (Teng (2002, dalam Salatin, Darminto dan Sudjana, 2013) adalah: (a) profitabilitas yang negatif/menurun, (b) merosotnya posisi pasar, (c) posisi kas yang buruk/negatif/ketidakmampuan melunasi kewajiban-kewajiban kas, (d) tingginya perputaran karyawan/rendahnya moral, (e) penurunan volume penjualan, (f) penurunan nilai penjualan, (g) ketergantungan terhadap utang, dan (h) kerugian yang selalu diderita dari operasinya.

Faktor-faktor yang menyebabkan terjadinya kebangkrutan pada perusahaan: Pertama, faktor umum (Adnan dan Arisudhana, 2010) meliputi: (a) Sektor ekonomi, seperti gejala inflasi/deflasi, kebijakan keuangan, suku bunga dan devaluasi/ revaluasi, surplus/defisit dalam hubungannya dengan perdagangan luar negeri. (b) Sektor sosial, misalnya perubahan gaya hidup, cara perusahaan berhubungan dengan karyawan serta kekacauan di masyarakat. (c) Sektor teknologi, meliputi biaya penggunaan teknologi informasi untuk pemeliharaan dan implementasi yang tidak terencana, sistemnya tidak terpadu dan para manajer pengguna kurang profesional. (d) Sektor pemerintah, seperti kebijakan pencabutan subsidi pada perusahaan dan industri, pengenaan tarif ekspor dan impor barang yang berubah, kebijakan UU baru bagi perbankan atau tenaga kerja dan lain-lain.

Kedua, faktor eksternal perusahaan, terdiri atas: (a) sektor pelanggan, seperti identifikasi sifat konsumen untuk menghindari kehilangan konsumen, menciptakan 
peluang, menemukan konsumen baru, menghindari menurunnya hasil penjualan dan mencegah konsumen berpaling ke pesaing. (b) Sektor pemasok, (c) Sektor pesaing, dan (d) Faktor internal perusahaan.

\section{Rasio Likuiditas}

Rasio likuiditas yang menunjukkan kemampuan perusahaan dalam memenuhi kewajiban jangka pendek yang harus segera dipenuhi perusahaan. Ukuran rasio likuiditas terdiri dari: (a) Current Rasio, perbandingan antara jumlah aktiva lancar dengan hutang lancar. (b) Quick Rasio, menunjukkan kemampuan perusahaan untuk membayar utang dengan aktiva yang likuid. (c) Cash rasio, rasio ini digunakan untuk mengetahui kemampuan perusahaan untuk membayar kewajiban-kewajiban yang jatuh tempo.

\section{Rasio Solvabilitas}

Solvabilitas membandingkan antara total aktiva dengan total utang. Perusahaan dikatakan dalam kondisi ideal, apabila perusahaan dapat memenuhi kewajiban jangka pendek dan jangka panjangnya. Analisis solvabilitas bertujuan untuk mengetahui apakah kekayaan perusahaan mampu untuk mendukung kegiatan perusahaan tersebut. Tingkat solvabilitas dapat dihitung dengan menggunakan rasio keuangan : (a) Total Debt to Total Asset Ratio, mengukur persentase besarnya dana yang berasal dari hutang. (b) Debt to Equity Rasio, merupakan imbangan antara hutang yang dimiliki perusahaan dengan modal sendiri. Semakin tinggi rasio ini berarti modal sendiri semakin sedikit dibandingkan dengan hutangnya.

\section{Rasio Profitabilias}

Profitabilitas merupakan hal yang penting untuk mengetahui perkembangan suatu perusahaan karena dengan profitabilitas manajemen dapat mengukur kemampuan dan kesuksesan perusahaan dalam menggunakan aktivanya. Profitabilitas adalah kemampuan suatu perusahaan untuk memperoleh pendapatan diatas biaya-biaya yang diperhitungkan yang dapat diukur dengan menggunakan rasio-rasio keuangan yaitu: (a) Profit Margin, menggambarkan upaya untuk menekankan biaya sekecil mungkin guna mencapai keuntungan yang sebesarbesarnya, dengan membagi Earning After Tax (EAT) dengan total pendapatan. (b) Return on Aset (ROA) sering disebut rentabilitas ekonomis, merupakan ukuran kemampuan perusahaan dalam menghasilkan laba dengan semua aktiva yang dimiliki oleh perusahaan. (c) Return on Equity, sering disebut rate of return on Net Worth yaitu kemampuan perusahaan dalam menghasilkan keuntungan dengan modal sendiri yang dimiliki, sehingga ROE disebut juga sebagai rentabilitas modal sendiri.

\section{Altman Z-Score Models}

Model prediksi kebangkrutan perusahaan yang paling populer digunakan adalah yang dikembangkan oleh Edward. I. Altman tahun 1968 menggunakan metode Multiple Discriminat Analysis (MDA) atau Z-Score yang memberikan hasil prediksi dengan tingkat akurasi mencapai 95\% pada perusahaan manufaktur yang terdaftar di pasar saham Amerika Serikat selama satu tahun sebelum mengalami kebangkrutan. Bahkan, Altman berupaya untuk memperbaiki model prediksi ini agar digunakan oleh semua objek perusahaan yang berbeda-beda. Lebih lanjut, Othman (2011) menjelaskan bahwa Altman telah melakukan dua tahap modifikasi 
untuk penyempurnaan Z-Score Model. Z-Score model merupakan kombinasi dari lima rasio umum dengan pola sebagai berikut:

Dimana : $\begin{aligned} & \mathrm{Z}=0.012(\mathrm{X} 1)+0.014(\mathrm{X} 2)+0.033(\mathrm{X} 3)+0.006(\mathrm{X}) 4)+0.999(\mathrm{X} 5) \\ & \mathrm{X}_{1} \quad: \text { Working Capital/Total Assets, } \\ & \mathrm{X}_{2} \quad: \text { Retained Earnings/Total Assets } \\ & \mathrm{X}_{3} \quad: \text { Earnings before Interest and Taxes/Total Assets, } \\ & \mathrm{X}_{4} \quad: \text { Market Value Equity/Book Value of Total Liabilities, } \\ & \mathrm{X}_{5} \quad: \text { Sales/Total Assets, }\end{aligned}$

Nilai cut-off untuk Z-Score model ini melibatkan tiga zona yang memungkinkan apakah perusahaan berada dalam keadaan aman (skor $>=2,99$ ), wilayah abu-abu (skor 1,82 - 2,98) atau bahkan wilayah tidak aman/bermasalah (skor <1,81). Namun semakin lama hasil prediksi menunjukkan kemunduran sebab model ini dipukul rata penggunaannya untuk objek perusahaan yang berbeda. Dengan begitu Altman melakukan modifikasi yang dikenal dengan nama $Z$ '-Score Model, yang dirancang agar dapat digunakan untuk perusahaan swasta. Pola yang digunakan untuk model Altman modifikasi ini adalah:

$$
Z^{\prime}=0.717\left(X_{1}\right)+0.847\left(X_{2}\right)+3.107\left(X_{3}\right)+0.420\left(X_{4}\right)+0.998\left(X_{5}\right)
$$

Nilai cut-off untuk $Z$ '-Score model ini meletakkan skor $>=2.9$ pada wilayah aman, skor 1.23-2.9 adalah wilayah abu-abu, sedangkan $<1.23$ merupakan wilayah tidak aman. Kemudian, Altman kembali melakukan modifikasi sebagai bentuk penyempurnaan dari model-model prediksi terdahulu dengan maksud agar model prediksi ini dapat digunakan untuk perusahaan non manufaktur.

Seiring berjalannya waktu, perkembangan pasar obligasi dan investasi pada obligasi sudah menjalar ke negara-negara berkembang. Untuk dapat memprediksi kemungkinan kebangkrutan dari perusahaan-perusahaan penerbit obligasi korporasi di negara berkembang (emerging market), maka Altman memodifikasi modelnya yang pertama. Altman melakukan modifikasi model untuk meminimalisir efek industri karena keberadaan variabel perputaran aset (X5) yaitu rasio penjualan terhadap total aset. Selain eliminasi Variabel X5, Altman juga mengganti pembilang pada rasio X4, yaitu dari nilai pasar ekuitas menjadi nilai buku ekuitas, tujuannya agar EM Z-Score juga dapat digunakan pada perusahaan yang tidak go publik. Model ini digunakan oleh Altman pada tahun 2002 untuk meneliti tingkat kesehatan keuangan perusahaan non manufaktur di Amerika Serikat. Maka dari itu, model prediksi yang dikenal dengan nama Altman's Emerging Market Z-Score model (EM Z"Score) adalah sebagai berikut:

$$
\mathrm{Z}^{\prime \prime}=6.56(\mathrm{X} 1)+3.26(\mathrm{X} 2)+6.72(\mathrm{X} 3)+1.05(\mathrm{X} 4)
$$

Dimana : $\quad \mathrm{X} 1=$ Working Capital to Total Assets

$\mathrm{X} 2=$ Retained Earnings to Total Assets

$\mathrm{X} 3=\mathrm{EBIT}$ to Total Assets

X4 = Book Value of Equity to Total Liabilities

Altman (2002) menambahkan nilai konstan +3.25 sehingga untuk standarisasi skor nol (0) disamakan dengan default obligasi. Dengan kata lain, 3.25 merupakan faktor skala setara dengan 0 hingga patokan khas perusahaan yang telah gagal pada obligasi korporasi mereka. Dengan demikian, nilai koefisien dari masing-masing 
variable adalah skor >=2.6 daerah aman, skor 1,1 - 2,6 adalah daerah abu-abu sedangkan skor $<1,1$ adalah daerah rawan/bangkrut.

\section{Penelitian Terdahulu}

Hully (2012) melakukan analisis komparatif tingkat risiko keuangan Bank Umum Konvensional dan Bank Umum Syariah periode 2007-2010 menggunakan tTest sebagai alat uji statistiknya. Penelitiannya menunjukkan bahwa secara umum pertumbuhan quick ratio (likuiditas) dan CAR (solvabilitas) bank umum konvensional dan bank umum syariah mengalami fluktuasi atau tidak stabil. Sedangkan ROE (rentabilitas) bank umum konvensional mengalami peningkatan dari tahun ke tahun berbeda dengan bank umum syariah yang mengalami fluktuasi dari tahun ke tahun. Dari hasil perhitungan Altman Z-Score terlihat bahwa bank umum konvensional dan bank umum syariah dalam kategori tingkat risiko tinggi. Selain itu, terdapat perbedaan tingkat solvabilitas antar bank namun tidak terdapat perbedaan signifikan likuiditas, rentabilitas dan Z'-Score terhadap tingkat resiko keuangan bank.

Kumulasari (2012) menganalisis perbandingan risiko bank umum syariah dengan risiko bank konvensional di Indonesia tahun 2008-2012 menggunakan uji Independent Sample t-Test, menunjukkan tidak terdapat perbedaan anatara bank umum konvensional dan bank umum syariah dalam proxy Non Performing Financing terhadap Non Performing Loan (NPF/NPL). Sedangkan pada proxy Financing to Deposit Ratio terhadap Loan to Deposit Ratio (FDR/LDR) terdapat perbedaan yang signifikan antara bank umum konvensional dan bank umum syariah dimana FDR bank umum syariah lebih besar daripada LDR bank konvensional. Othman (2011) membandingkan prediksi kebangkrutan antara Bank Islam dan Bank Konvensional di Malaysia tahun 2008-2010 menggunakan Z"'-Score model dengan teknik multiple discriminant analysis. Othman menemukan bahwa Bank Islam dan Bank Konvensional berada pada skala sehat, namun perlu diwaspadai untuk Bank Islam menunjukkan hasil Z"'-Score yang mengalami penurunan dibandingkan dengan Bank Konvensional.

Yunita (2012) melakukan analisis komparatif rasio kebangkrutan Altman antara bank konvensional dan bank syariah di Indonesia tahun 2011 dengan teknik analisis Mann Whitney $U$. Hasilnya menunjukkan bahwa terdapat perbedaan working capital to total assets, retained earning to total assets, earning before interest and tax, book value of equity to book value of debt, sales to total assets antara perbankan syariah dan perbankan konvensional.

Fauzi (2013) menganalisis perbandingan efisiensi bank umum syariah dan bank umum konvensional dengan metode data envelopment analysis (DEA) pada Bank BRI dan BSM tahun 2007-2011 dengan pendekatan frontier dan uji mann whitney. Ia menunjukkan bahwa tidak terdapat perbedaan yang signifikan antara efisiensi bank umum syariah dan bank umum konvensional dalam Constant Return to Scale (CRS), Variable Return to Scale (VRS) maupun Skala Efisiensi (SE). Hafifah (2013) melakukan analisis komparatif risiko keuangan bank mandiri konvensional dan Bank Syariah Mandiri dengan menggunakan analisis rasio keuangan dan analisis Z-Score. Hasilnya terdapat perbedaan risiko keuangan Bank mandiri konvensional dan Bank Syariah Mandiri. Secara umum, rasio keuangan dan nilai ZScore Bank Syariah Mandiri lebih baik dari pada bank mandiri konvensional. Dengan kata lain, risiko keuangan bank syariah mandiri lebih rendah dibandingkan bank mandiri konvensional. 
Safitri (2014) melakukan analisis komparatif resiko keuangan antara perbankan konvensional dan perbankan syariah tahun 2010-2012 menggunakan analisis diskriminan Z-Score dan diperoleh hasil bahwa bank konvensional lebih berisiko tinggi dibandingkan bank syariah. Walaupun hasil yang diperoleh menunjukkan bahwa kedua bank sama-sama berisiko tinggi, tapi bank konvensional lebih berisiko dibanding bank syariah, karena memiliki nilai rata-rata Z- Score $0,7417(0,7417<1,81)$. Disisi lain, bank syariah juga memiliki risiko tinggi tapi lebih rendah dengan nilai rata-rata Z-Score nya berada dibawah $1,81(1,55<$ 1,81).

Beberapa peneliti sebelumnya yang membandingakan prediksi kebangkrutan bank syariah dan konvensional menemukan bahwa terdapat perbedaan rasio working capital to total assets, rasio retained earning to total assets, rasio earning before interest and tax to total assets, rasio book value of equity to book value of debt, serta perbedaan rasio sales to total assets bank konvensional dan bank syariah tahun 2011 (Yunita, 2012). Nurwati (2014) juga membahas tentang analisis komparatif risiko keuangan pada PT. Bank Negara Indonesia (BNI) dan PT. Bank Syariah Mandiri (BSM) di Indonesia menyebutkan bahwa nilai Z-score BNI lebih rendah dibanding dengan BSM, berarti tingkat risiko keuangan BNI lebih rendah dibandingkan BSM. Dengan demikian, BNI lebih berisiko mengalami kebangkrutan dibandingkan BSM.

\section{Hipotesis}

Dari uraian di atas, maka hipotesis dari penelitian ini adalah:

$\mathrm{H}_{01} \quad$ : Tidak terdapat perbedaan prediksi kebangkrutan bank syariah dan bank konvensional jika dilihat dari rasio working capital to total assets.

$\mathrm{H}_{\mathrm{a} 1} \quad$ : Terdapat perbedaan prediksi kebangkrutan bank syariah dan bank konvensional jika dilihat dari rasio working capital to total assets.

$\mathrm{H}_{02}$ : Tidak terdapat perbedaan prediksi kebangkrutan bank syariah dan bank konvensional jika dilihat dari rasio retained earnings to total assets.

$\mathrm{H}_{\mathrm{a} 2} \quad$ : Terdapat perbedaan prediksi kebangkrutan bank syariah dan bank konvensional jika dilihat dari rasio retained earnings to total assets.

$\mathrm{H}_{03}$ : Tidak terdapat perbedaan prediksi kebangkrutan bank syariah dan bank konvensional jika dilihat dari rasio earning before interest and tax to total assets.

$\mathrm{H}_{\mathrm{a} 3} \quad$ : Terdapat perbedaan prediksi kebangkrutan bank syariah dan bank konvensional jika dilihat dari rasio earning before interest and tax to total assets.

\section{METODE PENELITIAN}

Penelitian ini merupakan penelitian eksplanatory dengan pendekatan kuantitatif. Karakteristik penelitian bersifat replikasi, dimana hasil uji hipotesis harus didukung oleh penelitian-penelitian sebelumnya, yang diulang dengan kondisi lain yang kurang lebih sama (Sugiyono, 2012). Penelitian ini dimulai dengan menentukan bank apa saja yang tergolong dalam jenis perbankan konvensional dan perbankan syariah yang terdaftar di Bank Indonesia selama tahun 2012-2014. Selanjutnya dilakukan pengumpulan laporan keuangan perusahaan, kemudian, dilakukan analisis prediksi menggunakan Altman's EM Z-Score untuk mengetahui kondisi keuangan perusahaan. Setelah itu, kondisi keuangan perusahaan tersebut dikelompokkan dalam tiga zona menurut Z"-Score dan dilakukan analisis data untuk mengetahui 
perbandingan apakah terdapat perbedaan hasil pediksi kebangkrutan bank konvensional dan bank syariah menggunakan rasio-rasio Z"'-Score.

Populasi penelitian seluruh Bank Umum Syariah dan Bank Umum Konvensional yang terdaftar di Bank Indonesia periode 2012-2014. Pengambilan sampel menggunakan metode purposive sampling yang sesuai dengan kriteria yang diperlukan, yaitu: (a) Bank syariah dan bank konvensional yang menyajikan laporan keuangan periode 2012-2014 dalam mata uang Rupiah (Rp), serta dapat memenuhi variabel penelitian, (b) Bank konvensional yang terdaftar di BEI dan tidak memiliki unit usaha syariah, (c) Bank syariah yang termasuk kategori Bank Umum Syariah (BUS), bukan unit usaha syariah. Dari 34 total perbankan syariah yang memenuhi kriteria penelitian adalah 11 Bank Umum Syariah, sedangkan dari 149 perbankan konvensional yang dijadikan sampel, 23 Bank Umum Konvensional. Data dikumpulkan menggunakan metode dokumentasi berupa laporan keuangan perbankan syariah dan konvensional dari situs website perbankan dan situs www.idx.co.id.

\section{Variabel Penelitian}

Prediksi kebangkrutan perbankan telah mengalami modifikasi yang disebut Altman's Emerging Market Z-Score Model atau Z'-Score Model dengan pola prediksi sebagai berikut (Altman, 2002),:

$$
\mathrm{Z}^{\prime \prime}=6.56(\mathrm{X} 1)+3.26(\mathrm{X} 2)+6.72(\mathrm{X} 3)+1.05(\mathrm{X} 4)
$$

Dimana: $\mathrm{X} 1=$ Working Capital to Total Assets

$\mathrm{X} 2$ = Retained Earnings to Total Assets

$\mathrm{X} 3=$ EBIT to Total Assets

$\mathrm{X} 4$ = Book Value of Equity to Total Liabilities

Berikut penjelasan masing-masing variabel Altman EM Z-Score di atas:

1. Working Capital to Total Assets ( $X_{1}$ )

Adalah kemampuan perusahaan untuk menghasilkan modal kerja bersih dari keseluruhan total aktiva yang dimilikinya. Modal kerja adalah perbedaan antara aset lancar dan kewajiban lancar. Modal kerja bersih yang negatif kemungkinan besar akan menghadapi masalah dalam menutupi kewajiban jangka pendeknya karena tidak tersedianya aktiva lancar yang cukup untuk menutupi kewajiban tersebut. Sebaliknya perusahaan dengan modal kerja bersih yang positif jarang sekali menghadapi kesulitan dalam melunasi kewajibannya.

$$
\text { Rumus X1 }=\frac{\text { Aset lancar }- \text { hutang lancar }}{\text { Total aset }}
$$

\section{Retained Earnings to Total Assets (X2)}

Menunjukkan kemampuan perusahaan menghasilkan laba ditahan dari total aktiva perusahaan Laba ditahan terjadi karena pemegang saham biasa mengizinkan perusahaan untuk menginvestasikan kembali laba yang tidak didstribusikan sebagai dividen. Usia suatu perusahaan akan dipertimbangkan dalam rasio ini. Perusahaan yang relatif muda akan mungkin menunjukkan retained earnings rendah terhadap total assets karena belum memiliki waktu yang lama untuk membangun keuntungan kumulatif.

$$
\text { Rumus X2 }=\frac{\text { Laba ditahan }}{\text { Total aset }}
$$

3. Earnings before Interest and Tax to Total Assets ( $\left.X_{3}\right)$ 
Menunjukkan kemampuan perusahaan untuk menghasilkan laba dari aktiva perusahaan, sebelum pembayaran bunga dan pajak. Laba sebelum pajak merupakan laba sebelum dikurangi dengan pajak dan ketentuan keuangan lainnya.

$$
\text { Rumus X2 }=\frac{\text { Pendapatan sebelum bunga dan pajak }}{\text { Total aset }}
$$

\section{Book Value of Equity to Total Liabilities ( $\left.X_{4}\right)$}

Digunakan untuk mengukur sejauh mana aktiva perusahaan dibiayai dari hutang, atau seberapa besar beban utang yang ditanggung perusahaan dibandingkan dengan aktivanya. Rasio ini digunakan untuk mengukur kemampuan perusahaan untuk membayar seluruh kewajibannya, baik jangka pendek maupun jangka panjang. Jika dari tahun ketahun nilai rasio book value of equity to total liabilities semakin meningkat, maka perusahaan tersebut diprediski mengalami distress. Namun, jika dari tahun ketahun nilai rasio book value of equity to total liabilities semakin menurun, maka perusahaan tersebut diprediksi mengalami non distress.

\section{Metode Analisis Data}

$$
\text { Rumus X2 }=\frac{\text { Nilai buku ekuitas }}{\text { Total hutang }}
$$

\section{Analisis Rasio Keuangan Altman EM Z-Score Model}

Analisis Altman EM Z- Score Model digunakan untuk menganalisis prediksi kebangkrutan bank syariah dan bank konvensional kemudian hasil dari prediksi tersebut dibandingkan untuk mengetahui apakah terdapat perbedaan prediksi kebangkrutan antara kedua bank. Langkah pertama adalah menghitung masingmasing rasio keuangan yang telah ditetapkan sebagai variabel penelitian dengan pola:

$$
\mathrm{Z}^{\prime \prime}=6.56(\mathrm{X} 1)+3.26(\mathrm{X} 2)+6.72(\mathrm{X} 3)+1.05(\mathrm{X} 4)
$$

Perhitungan zona untuk hasil persamaan diatas adalah:

a. Z"-Score $>=2.6$ maka perusahaan diklasifikasikan aman

b. 1,1<Z"'-Score <2,6 maka perusahaan diklasifikasikan abu-abu

c. Z"-Score $<1,1$ maka perusahaan diklasifikasikan rawan/bangkrut.

\section{Uji Normalitas Data}

Dilakukan dengan menggunakan kolmogrov-Smirnov sebagai syarat melakukan uji mann whitney. Uji normalitas ini dilakukan dengan analisis statistik nonparametrik.

a. H0: Data residual berdistribusi normal

Jika hasil Uji K-S menunjukkan nilai probabilitas tidak signifikan pada 0,05 maka hipotesis nol diterima yang berarti data residual terdistribusi normal.

b. Ha: Data residual tidak berdistribusi normal

Jika hasil Uji K-S menunjukkan nilai probabilitas signifikan pada 0,05 maka hipotesis nol ditolak yang berarti data residual terdistribusi tidak normal (Purwanto, 2011).

\section{Uji Homogenitas}

Dilakukan untuk mengetahui keseragaman data penelitian, dengan menggunakan uji Levene. Nilai Levene hitung yang diperoleh kemudian dibandingkan dengan Levene tabel atau dapat juga menggunakan nilai perbandingan signifikansi dengan a 5\%. Jika nilai Levene hitung < Levene tabel atau P value $>5 \%$, maka analisis uji beda menggunakan uji Independent Sample T-test. Sebaliknya jika nilai Levene 
besar dari Levene tabel atau P Value $<5 \%$ maka analisis uji beda menggunakan U Mann Whitney (Ghozali, 2006).

\section{Analisis Crosstab}

Analisis crosstab pada prinsipnya menyajikan data dalam bentuk tabulasi yang meliputi baris dan kolom dan data untuk penyajian crosstab adalah data berskala nominal atau kategori (Ghozali, 2006).

\section{Uji Mann Whitney}

Majid (2015) menyatakan uji mann whitney digunakan untuk membandingkan dua sampel yang memiliki perbedaan jumlah data. Tujuannya adalah membandingkan dua kelompok independen yang mempunyai ukuran sampel berbeda. Kedua kelompok tersebut tidak memenuhi syarat untuk di ujikan melalui Uji $\mathrm{T}$ (Syarat Uji T adalah data terdistribusi normal dan data homogen). Syarat uji mann whitney sebagai berikut: (a) Probabilitas > 0,05 maka Ho diterima, yaitu tidak terdapat perbedaan prediksi kebangkrutan perbankan syariah dan perbankan konvensional. (b) Probabilitas < 0,05 maka Ha diterima, yaitu terdapat perbedaan prediksi kebangkrutan perbankan syariah dan perbankan konvensional.

\section{PEMBAHASAN HASIL UJI HIPOTESIS}

\section{Analisis Rasio Keuangan Altman Z"-Score Model}

Altman EM Z-Score model (Z"'-Score) menggunakan pola dan mengidentifikasi empat rasio yang digunakan dalam formulanya, yaitu:

$$
\mathrm{Z}^{\prime \prime}=6.56(\mathrm{X} 1)+3.26(\mathrm{X} 2)+6.72(\mathrm{X} 3)+1.05(\mathrm{X} 4)+3.25
$$

Dimana : $\quad \mathrm{X} 1=$ Working Capital to Total Assets (modal kerja terhadap total harta)

X2 = Retained Earnings to Total Assets (laba yang ditahan terhadap total harta)

$\mathrm{X} 3$ = EBIT to Total Assets (pendapatan sebelum bunga dan pajak terhadap total harta)

X4 = Book Value of Equity to Total Liabilities (Nilai buku ekuitas terhadap total hutang)

Untuk nilai Z"'-Score akan dibagi menjadi tiga kondisi yaitu aman (sehat) jika nilai Z"'-Score lebih besar dari $2.6(>=2.6)$ akan diberi kode satu (1), jika nilai Z"'-Score lebih besar dari 1.1 dan lebih kecil dari $2.6(>1.1-<2.6)$ berarti perusahaan diklasifikasikan dalam kondisi abu-abu dan akan diberi kode dua (2), namun jika hasil Z"'-Score yang didapatkan kecil dari $1.1(<1.1)$ maka perusahaan diklasifikasikan dalam kondisi bangkrut dengan kode tiga (3). Dari persamaan di atas peneliti menganalisis 11 sampel perbankan syariah dari 34 perbankan syariah, dengan mengambil keseluruhan populasi perbankan syariah dan 23 sampel perbankan konvensional dari 149 perbankan konvensional yang memenuhi kriteria penelitian. Perhitungan Z"'-Score menggunakan empat rasio keuangan yang penulis dapatkan sesuai dengan urutan yang telah tersedia pada laporan keuangan perbankan. Maka berikut hasil Z"-Score untuk perbankan syariah:

Tabel 1. Hasil Altman EM Z-Score Perbankan Syariah

\begin{tabular}{|c|c|c|c|c|c|}
\hline \multirow[b]{2}{*}{ No } & \multirow[b]{2}{*}{ Nama Bank } & \multicolumn{3}{|c|}{ Hasil Altman EM Z-Score Model } & \multirow{2}{*}{$\begin{array}{l}\text { Rata-rata } \\
\text { Z"- Score }\end{array}$} \\
\hline & & 2012 & 2013 & 2014 & \\
\hline 1 & Bank BCA Syariah, PT & 4,39 & 4,00 & 5,00 & 4,46 \\
\hline
\end{tabular}




\begin{tabular}{|c|l|r|r|r|l|}
\hline 2 & Bank BNI Syariah, PT & 3,92 & 3,95 & 4,27 & 4,05 \\
\hline 3 & Bank BRI Syariah, PT & 4,08 & 5,31 & 5,25 & 4,88 \\
\hline 4 & Bank Jabar Banten Syariah, PT & 4,33 & 4,52 & 4,29 & 4,38 \\
\hline 5 & Bank Maybank Syariah Indonesia, PT & 7,54 & 7,29 & 7,39 & 7,41 \\
\hline 6 & Bank Muamalat Indonesia, PT & 3,85 & 4,01 & 4,00 & 3,96 \\
\hline 7 & Bank Panin Syariah, PT, Tbk & 5,38 & 5,00 & 5,02 & 5,13 \\
\hline 8 & Bank Bukopin Syariah, PT & 3,84 & 4,00 & 4,10 & 3,98 \\
\hline 9 & Bank Syariah Mandiri, PT & 4,20 & 4,13 & 3,99 & 4,11 \\
\hline 10 & Bank Syariah Mega Indonesia, PT & 4,16 & 4,12 & 4,22 & 4,16 \\
\hline 11 & Bank Victoria Syariah, PT & 5,00 & 4,57 & 4,56 & 4,71 \\
\hline & \multicolumn{2}{|c|}{ Rata-rata Z'-Score Bank Syariah } \\
\hline
\end{tabular}

Sumber : IDX, BI data diolah 2015 oleh penulis

Berdasarkan tabel 1 diatas ditemukan bahwa keseluruhan sampel bank syariah berada dalam posisi sehat, karena berdasarkan rentang pengambilan sampel penelitian, perbankan syariah tahun 2012 - 2014 tidak ada yang diklasifikasikan sebagai bank abu-abu bahkan bangkrut. Hal ini terbukti dari hasil Z"'-Score yang didapatkan setiap tahun rata-rata diatas angka empat yang berarti bank syariah secara keseluruhan berhasil mempertahankan kinerja keuangan perusahaannya.

Bank Maybank Syariah Indonesia yang setiap tahunnya memperoleh Z"'-Score mencapai angka 7, karena terbukti bahwa empat variabel dari Z"'-Score tidak mengalami perubahan yang signifikan. Ini berarti Bank Maybank Syariah berhasil mempertahankan kondisi keuangan perusahaannya selama tiga tahun berturutturut. Sedangkan PT Bank Syariah Mandiri mengalami penurunan Z"-Score dalam kurun waktu 2012 - 2014, yang disebabkan terjadinya penurunan nilai modal kerja terhadap total aktiva perbankan syariah pada tahun 2012-2014 yaitu 0.05116, 0.05003 dan kembali turun menjadi 0.03745 . Hal ini dikarenakan hutang lancar perbankan yang meningkat tiap tahunnya sehingga modal kerja menjadi menurun. Maka Bank Syariah Mandiri harus memberikan perhatian khusus terhadap kondisi keuanggan perusahaannya terutama untuk modal kerja perbankan agar tidak kembali turun untuk tahun-tahun berikutnya dan hasil Z"-Score tidak mencapai titik abu-abu, walaupun pada kenyataannya hasil Z"'-Score menunjukkan rata-rata Z"'-Score 4.66, yang berarti secara rata-rata perbankan syariah berada pada rentang aman/sehat. Sedangkan hasil Z"-Score perbankan konvensional sebagai berikut:

Tabel 2. Hasil Altman EM Z-Score Perbankan Konvensional

\begin{tabular}{|c|l|c|c|c|c|}
\hline \multirow{2}{*}{ Na } & \multicolumn{2}{|c|}{ Nama Bank } & \multicolumn{2}{c|}{ Hasil Altman EM Z-Score Model } & \multirow{2}{*}{$\begin{array}{c}\text { Rata Z"- } \\
\text { Score }\end{array}$} \\
\cline { 3 - 5 } 1 & Bank Rakyat Indonesia Agro Niaga & $\mathbf{2 0 1 2}$ & $\mathbf{2 0 1 3}$ & $\mathbf{2 0 1 4}$ & \\
\hline 2 & Bank MNC Internasional Tbk & 4,12 & 4,86 & 4,81 & 4,62 \\
\hline 3 & Bank Capital Indonesia Tbk & 4,43 & 4,59 & 4,51 & 4,51 \\
\hline 4 & Bank Ekonomi Raharja Tbk & 4,58 & 4,72 & 4,81 & 4,70 \\
\hline 5 & Bank Nusantara Parahyangan Tbk & 4,33 & 4,59 & 4,87 & 4,59 \\
\hline 6 & Bank Mutiara Tbk & 6,03 & 1,92 & 1,65 & 3,20 \\
\hline 7 & Bank Danamon Indonesia Tbk & 5,46 & 5,29 & 5,30 & 5,35 \\
\hline 8 & Bank Pundi Indonesia Tbk & 3,97 & 3,99 & 4,24 & 4,07 \\
\hline 9 & Bank QNB Kesawan Tbk & 4,72 & 4,42 & 4,40 & 4,51 \\
\hline 10 & Bank Mandiri (Persero) Tbk & 4,91 & 4,80 & 5,02 & 4,91 \\
\hline
\end{tabular}




\begin{tabular}{|l|l|c|c|c|c|}
\hline 11 & Bank Bumi Artha Tbk & 4,84 & 4,83 & 4,72 & 4,80 \\
\hline 12 & Bank Internasional Indonesia Tbk & 4,49 & 4,46 & 4,66 & 4,54 \\
\hline 13 & Bank Permata Tbk & 4,28 & 4,06 & 3,85 & 4,06 \\
\hline 14 & Bank Sinar Mas Tbk & 4,18 & 4,65 & 4,61 & 4,48 \\
\hline 15 & Bank of India Indonesia Tbk & 5,06 & 4,83 & 4,70 & 4,86 \\
\hline 16 & Bank Tabungan Pensiunan Nasional & 5,21 & 5,34 & 5,60 & 5,38 \\
\hline 17 & Bank Victoria Internasional Tbk & 4,56 & 4,51 & 4,56 & 4,54 \\
\hline 18 & Bank Artha Graha International Tbk & 4,18 & 4,72 & 4,59 & 4,50 \\
\hline 19 & Bank Mayapada International Tbk & 4,21 & 4,52 & 4,48 & 4,40 \\
\hline 20 & Bank Windu Kentjana International & 4,62 & 4,71 & 4,64 & 4,66 \\
\hline 21 & Bank Mega Tbk & 4,27 & 4,00 & 4,25 & 4,18 \\
\hline 22 & Bank NISP OCBC Tbk & 4,69 & 4,89 & 5,03 & 4,87 \\
\hline 23 & Bank Himpunan Saudara 1906 Tbk & 4,41 & 6,22 & 4,80 & 5,14 \\
\hline \multicolumn{2}{|r|}{ Rata-rata Z'-Score Bank Konvensional } & & $\mathbf{4 , 5 7}$ \\
\cline { 2 - 6 }
\end{tabular}

Sumber : IDX, BI data diolah 2015 oleh penulis

Hasil Z"'-Score untuk perbankan konvensional (tabel 2) menunjukkan bahwa kondisi keuangan perbankan konvensional mengalami fluktuasi. Ditemukan satu perbankan konvensional berada dalam kondisi abu-abu dan 29 berada dalam kondisi sehat. Perbankan konvensional dengan hasil Z"'-Score paling tinggi adalah PT. Bank Danamon Indonesia Tbk dan PT Bank Tabungan Pensiunan Nasional Tbk karena terbukti hasil Z"'-Score mencapai angka 5 setiap tahunnya, karena dari 4 variabel Z"'-Score tidak mengalami perubahan yang signifikan tiap tahunnya, berarti bahwa PT. Bank Danamon Indonesia Tbk dan PT. Bank Tabungan Pensiunan Nasional Tbk berhasil mempertahankan kondisi keuangan perbankannya.

Sedangkan PT. Bank Mutiara Tbk mengalami penurunan nilai Z''-Score hingga mencapai titik abu-abu pada tahun 2013 dan 2014. Hal ini disebabkan nilai laba ditahan terhadap total aktiva mengalami penurunan yang signifikan pada tahun 2013 - 2014. Pada tahun 2012 nilai laba ditahan terhadap total aktiva yaitu 0.52523 namun pada tahun berikutnya turun menjadi -0.62670 dan 0.77222. Penurunan nilai ini mungkin disebabkan biaya operasional dan non operasional PT. Bank Mutiara Tbk yang meningkat sehingga perolehan laba perbankan mengalami penurunan, dan laba yang tidak dibagikan tersebut mengalami penurunan. Walapun pada kenyataannya secara rata-rata bank konvensional berada pada posisi aman/sehat karena memperoleh nilai Z"'-score rata-rata 4.57.

Dari hasil penjabaran diatas diketahui bahwa bank syariah dan bank konvensional Indonesia berada dalam keadaan aman, karena berhasil memperoleh nilai rata-rata Z''-Score diatas angka empat. Namun dari rata-rata Z"'-score tersebut terlihat bahwa bank syariah lebih stabil dibandingkan bank konvensional karena nilai rata-rata bank syariah 4.66 lebih besar dibandingkan dengan nilai ratarata Z"'-Score bank konvensional yaitu 4.57. Hal ini dikarenakan tidak satupun bank syariah yang diklasifikasikan sebagai daerah abu-abu bahkan bangkrut, sedangkan terdapat satu bank konvensional yang diklasifikasikan berada pada daerah abuabu. Setelah diperoleh rasio keuangan tersebut sebelum masuk kepada pengujian hipotesis, maka dilakukan terlebih dahulu uji normalitas dan uji homogenitas data.

\section{Uji Normalitas Data}


Uji normalitas menggunakan analisis kolmogorov-smirnov dengan tingkat signifikansi $5 \%$ menunjukkan bahwa rasio working capital to total assets dengan Asymp. Sig. (2-tailed) $0.002<0.005$ berarti data terdistribusi tidak normal, untuk rasio retained earnings to total assets dengan Asymp. Sig. (2-tailed) $>0.05$ dan EBIT to total assets dengan Asymp. Sig. (2-tailed) $0.546>0.05$ maka data terdistribusi secara normal, sedangkan untuk book value of equity to total liabilities dengan Asymp. Sig. (2-tailed) $0.000<0.05$ maka hal ini berarti data terdistribusi secara tidak normal.

Tabel 3. Uji Normalitas Data Perbankan Syariah One-Sample Kolmogorov Smirnov Test

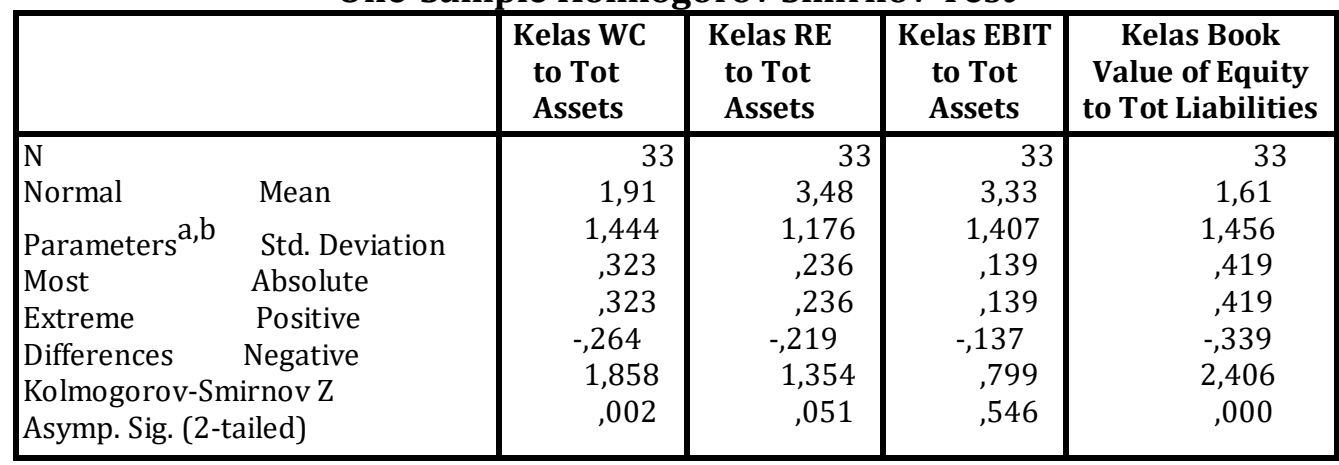

a. Test distribution is Normal.

b. Calculated from data.

Sumber: SPSS, data diolah 2015 oleh penulis

Sedangkan hasil uji statistik Kolgomogrov-Smirnov (tabel 4), menunjukkan rasio working capital to total assets dengan Asymp. Sig. (2-tailed) 0.005< 0.05, retained earnings to total assets dengan Asymp. Sig. (2-tailed) $0.000<0.05$, EBIT to total assets dengan Asymp. Sig. (2-tailed) $0.000<0.05$, dan book value of equity to total liabilities dengan Asymp. Sig. (2-tailed) $0.000<0.000$ maka data terdistribusi tidak normal.

Tabel 4. Uji Normalitas Data Perbankan Konvensional

One-Sample Kolmogorov-Smirnov Test

\begin{tabular}{|c|c|c|c|c|}
\hline & $\begin{array}{l}\text { Working Capital } \\
\text { to Total Assets }\end{array}$ & $\begin{array}{c}\text { Retained } \\
\text { Earnings to } \\
\text { total Assets }\end{array}$ & $\begin{array}{c}\text { EBIT to Total } \\
\text { Assets }\end{array}$ & $\begin{array}{c}\text { Book Value of } \\
\text { Equity to Total } \\
\text { Liabilities }\end{array}$ \\
\hline $\begin{array}{l}\text { N } \\
\text { Normal Mean } \\
\text { Parameters }{ }^{\mathrm{a}, \mathrm{b}} \quad \text { Std. Deviation } \\
\quad \text { Absolute } \\
\text { Most Extreme } \\
\quad \text { Positive } \\
\text { Differences } \\
\quad \text { Negative } \\
\text { Kolmogorov-Smirnov Z } \\
\text { Asymp. Sig. (2-tailed) }\end{array}$ & $\begin{array}{r}69 \\
, 105024 \\
, 0386692 \\
, 058 \\
\\
, 051 \\
\\
-, 058 \\
, 482 \\
, 005\end{array}$ & $\begin{array}{r}69 \\
, 028446 \\
, 1467021 \\
, 296 \\
, 245 \\
\\
-, 296 \\
2,462 \\
, 000\end{array}$ & $\begin{array}{r}69 \\
, 058448 \\
, 0201331 \\
, 096 \\
, 096 \\
\\
-, 082 \\
, 794 \\
, 000\end{array}$ & $\begin{array}{r}69 \\
, 137376 \\
, 0499220 \\
, 134 \\
, 134 \\
\\
-, 121 \\
1,116 \\
, 000\end{array}$ \\
\hline
\end{tabular}

Sumber: SPSS, data diolah 2015 oleh penulis

Karena sebagain besar data perbankan syariah dan konvensional terdistribusi secara tidak normal maka untuk pengujian selanjutnya harus menggunakan uji non parametrik. 


\section{Uji Homogenitas}

Pengujian homogenitas dilakukan menggunakan uji Levene dengan kriteria nilai probabilitas lebih besar dari level of significant $(\mathrm{a}=5 \%)$, maka data bank syariah dan konvensional dinyatakan homogen. Perolehannya sebagai berikut:

Tabel 5. Hasil Uji Homogenitas

Test of Homogeneity of Variances

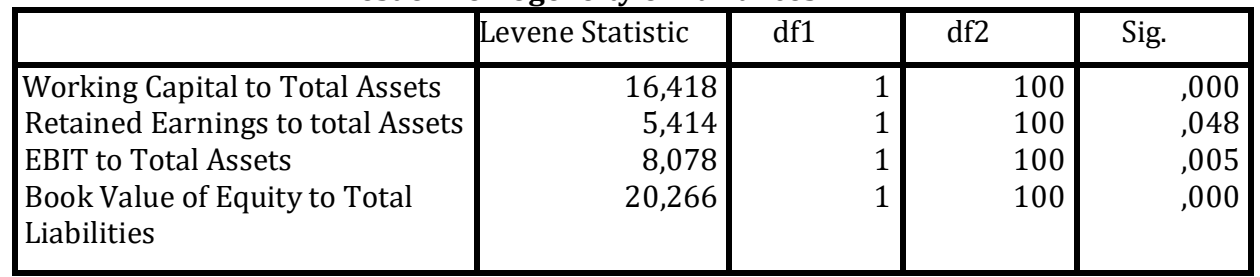

Sumber : SPSS, data diolah 2015 oleh penulis

Berdasarkan hasil uji homogenitas di atas menunjukkan bahwa levene statistic dengan sig. $<0.05$ maka nilai masing-masing rasio antara perbankan syariah dan perbankan konvensional berasal dari varian yang tidak homogen.

\section{Distibusi Frekuensi, Analisis Crosstab dan Uji Man Whitney Working Capital to Total Assets}

Tabel frekuensi working capital to total assets untuk bank syariah pada tabel 6 menunjukkan bahwa bank syariah mayoritas berada pada rentang nilai 0.00155 hingga 0.0776 , hal ini terbukti bahwa sekitar $50 \%$ atau 17 perusahaan berada pada rentang nilai tersebut.

Tabel 6. Frekuensi Working Capital to Total Assets Bank Syariah

\begin{tabular}{|c|c|c|}
\hline Kelas & Interval & Frekuensi \\
\hline 1 & $0.00155-0.0776$ & 17 \\
\hline 2 & $0.0777-0.1537$ & 11 \\
\hline 3 & $0.1538-0.22987$ & 2 \\
\hline 4 & $0.22988-0.30595$ & 0 \\
\hline 5 & $0.30596-0.38203$ & 0 \\
\hline 6 & $0.38204-0.45811$ & 3 \\
\hline \multicolumn{2}{|c|}{ Sumber: IDX, BI data diolah 2015 oleh penulis } \\
\hline
\end{tabular}

Disisi lain, tabel 7 menunjukkan bahwa perbankan konvensional mayoritas berada pada rentang nilai 0.06393 hingga 0.1302 , karena terbukti bahwa terdapat 46 perbankan konvensional atau sekitar 50\% lebih berada pada rentang nilai tersebut. Jika dibandingkan dengan rasio working capital to total assets bank syariah mayoritas hanya pada rentang nilai 0.00155 hingga 0.0776 , namun perbankan konvensional mayoritas berada pada rentang 0.06393 hingga 0.1302 .

Tabel 7. Frekuensi Working Capital to Total Assets Bank Konvensional

\begin{tabular}{|c|c|c|}
\hline Kelas & Interval & Frekuensi \\
\hline 1 & $-0.00235-0.03078$ & 1 \\
\hline 2 & $0.03079-0.06392$ & 7 \\
\hline 3 & $0.06393-0.09706$ & 20 \\
\hline 4 & $0.09707-0.1302$ & 26 \\
\hline 5 & $0.1303-0.16343$ & 12 \\
\hline 6 & $0.16344-0.19657$ & 2 \\
\hline 7 & $0.19658-0.22971$ & 1 \\
\hline
\end{tabular}

Sumber: IDX, BI data diolah 2015 oleh penulis 
Penjelasan lebih lanjut akan terlihat pada hasil crosstabulation working capital to total assets untuk bank syariah dan bank konvensional dibawah ini:

Tabel 8. Working Capital to Total Assets Bank Syariah Working Capital to Total Assets-Kondisi Keuangan Crosstabulation Count

\begin{tabular}{|ll|r|r|}
\hline Keterangan & $\begin{array}{c}\text { Kelas Kebangkrutan } \\
\text { Bank Syariah }\end{array}$ & Total \\
\cline { 3 - 3 } & & \multicolumn{1}{|c|}{ Aman } & \\
\hline \multirow{2}{*}{ Kelas WC to Tot Assets } & & 17 & 17 \\
Total & $0.00155-0.07762$ & 11 & 11 \\
& $0.07763-0.1537$ & 2 & 2 \\
& $0.38204-0.45811$ & 3 & 3 \\
\hline
\end{tabular}

Sumber : SPSS, data diolah 2015 oleh penulis

Hasil crosstabulation untuk working capital to total assets perbankan syariah menunjukkan bahwa pada distribusi frekuensi 0.00155 hingga 0.0776 perbankan syariah dikategorikan pada posisi aman.

Tabel 9. Working Capital to Total Assets Bank Konvensional Working Capital to Total Assets-Kondisi Keuangan Crosstabulation Count

\begin{tabular}{|c|c|c|c|c|}
\hline \multirow{2}{*}{\multicolumn{2}{|c|}{ Keterangan }} & \multicolumn{2}{|c|}{$\begin{array}{c}\text { Kelas Kebangkrutan Bank } \\
\text { Konvensional }\end{array}$} & \multirow[t]{2}{*}{ Total } \\
\hline & & Aman & Abu-abu & \\
\hline Kelas WC to Tot Assets & $\begin{array}{l}-0.00235-0.03078 \\
0.03079-0.06392 \\
0.06393-0.09706 \\
0.09707-0.1302 \\
0.1303-0.16343 \\
0.16344-0.19657 \\
0.19658-0.22971\end{array}$ & $\begin{array}{r}1 \\
7 \\
19 \\
25 \\
12 \\
2 \\
1 \\
67\end{array}$ & $\begin{array}{l}0 \\
0 \\
1 \\
1 \\
0 \\
0 \\
0 \\
2\end{array}$ & $\begin{array}{r}1 \\
7 \\
20 \\
26 \\
12 \\
2 \\
1 \\
69\end{array}$ \\
\hline
\end{tabular}

Sumber : SPSS, data diolah 2015 oleh penulis

Sedangkan tabel diatas terlihat bahwa perbankan konvensional mayoritas dengan nilai rasio 0.06393 hingga 0.1302 berada pada posisi aman, namun pada rentang nilai rasio tersebut terdapat dua perbankan konvensional berada pada posisi abu-abu. Berikut hasil uji mann whitney dalam mengetahui perbedaan working capital to total assets bank syariah dan bank konvensional.

\section{Tabel 10. Hasil uji U Mann Whitney - Working Capital to Total Assets} Test Statistics ${ }^{\mathrm{a}}$ 


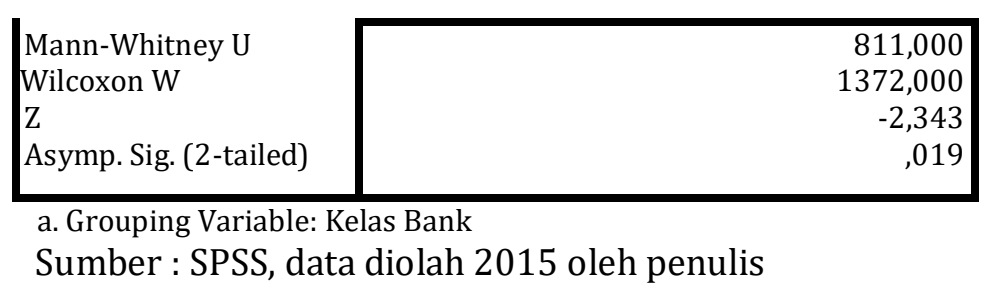

Tabel diatas terlihat bahwa nilai probabilitas Asymp. Sig. (2-tailed) $0.019<$ 0.05, maka $\mathrm{Ha}_{1}$ diterima yaitu terdapat perbedaan working capital to total assets antara bank syariah dan bank konvensional dalam memprediksi kebangkrutan perbankan. Penelitian ini sejalan dengan yang dilakukan oleh Yunita (2012) bahwa terdapat perbedaan working capital to total assets perbankan syariah dan konvensional, hal ini dikarenakan bank syariah membebankan margin lebih kecil dibandingkan bunga pada bank konvensional kepada nasabahnya. Dengan begitu, bank syariah tidak mengambil keuntungan yang tinggi atas pengelolaan dana nasabah tersebut. Hal ini jelas berbeda dengan perbankan konvensional yang membayar bunga saat penyimpanan dan menarik bunga pada saat memberi pinjaman. Sehingga keuntungan yang didapatkan lebih besar dibandingkan bank syariah dan modal kerja yang di dapatkan bank konvensional lebih tinggi dibandingkan bank syariah. Berikut perbandingan persentase rata-rata bagi hasil bank syariah dan suku bunga bank konvensional:

Tabel 11. Bagi Hasil Rata-rata Pembiayaan Bank Syariah dan Suku Bunga Rata-rata Kredit Bank Konvensional (Dalam Persentase)

\begin{tabular}{|l|c|c|c|}
\hline Jenis Bank & $\mathbf{2 0 1 2}$ & $\mathbf{2 0 1 3}$ & $\mathbf{2 0 1 4}$ \\
\hline Bank Umum Syariah & 10,41 & 10,09 & 11,45 \\
\hline Bank Umum Konvensional & 12,02 & 11,73 & 12,93 \\
\hline
\end{tabular}

Berdasarkan tabel diatas terlihat bahwa persentase rata-rata pembiayaan yang di dapatkan dari bank syariah relative lebih kecil dibandingkan bank konvensional. Rata-rata perolehan keuntungan paling banyak di dapatkan dari pembiayaan atau kredit, sehingga dengan persentase keuntungan yang besar otomatis akan memberikan tambahan modal kerja yang besar bagi perbankan. Maka, sesuai hasil dari distribusi frekuensi dan crosstab antara bank syariah dan bank konvensional, dapat dilihat bahwa mayoritas perolehan working capital to total assets bank konvensional lebih besar dibandingkan bank syariah yaitu 0.1302 lebih besar 0.0776, hal ini dikarenakan bunga yang ditetapkan bank konvensional lebih tinggi dibandingkan margin/bagi hasil bank syariah, jadi modal kerja mayoritas bank konvensional lebih besar dibandingkan bank konvensional.

Namun, jika dilihat perolehan nilai tertinggi rasio working capital to total assets dari distribusi frekuensi bank syariah yaitu 0.45811 lebih besar dibandingkan bank konvensional dengan nilai 0.229971. Selain itu, tidak terdapat satupun nilai working capital to total assets perbankan syariah bernilai negatif, hal ini berarti dalam perbankan syariah dapat menutupi kewajiban jangka pendeknya menggunakan pemanfaatan dari keseluruhan aktiva perbankan dibandingkan dengan perbankan konvensional. Maka dari itu, dalam hal prediksi kebangkrutan dari nilai working capital total assets bank syariah lebih stabil dibandingkan bank konvensional. Disimpulkan bahwa terdapat perbedaan working capital to total assets perbankan syariah dan perbankan konvensional dalam memprediksi kebangkrutan perbankan. 


\section{Retained Earnings to Total Assets}

Berdasarkan tabel frekuensi retained earnings to total assets bank syariah pada tabel 12, terlihat bahwa bank syariah mayoritas berada pada rentang nilai -0.00568 hingga 0.03779 , terbukti bahwa 23 perbankan berada pada rentang nilai tersebut.

Tabel 12. Tabel Frekuensi Retained Earnings to Total Assets Bank Syariah

\begin{tabular}{|c|c|c|}
\hline Kelas & Interval & Frekuensi \\
\hline 1 & $-0.04903--0.0273$ & 2 \\
\hline 2 & $-0.0274--0.00567$ & 2 \\
\hline 3 & $-0.00568-0.01605$ & 15 \\
\hline 4 & $0.01606-0.03779$ & 8 \\
\hline 5 & $0.03780-0.05953$ & 4 \\
\hline 6 & $0.05954-0.08127$ & 2 \\
\hline \multicolumn{2}{|l|}{ Sumber: IDX, BI data diolah 2015 oleh penulis } \\
\end{tabular}

Tetapi, tabel diatas menunjukkan bahwa perbankan konvensional mayoritas berada pada rentang nilai antara 0.33986 hingga 0.52521 , karena terbukti bahwa terdapat 40 perbankan konvensional berada pada rentang nilai tersebut. Jika dibandingkan dengan hasil distribusi frekuensi perbankan syariah mayoritas hanya berada pada rentang nilai -0.00568 hingga 0.03779 sedangkan mayoritas perbankan konvensional berada pada rentang nilai 0.33986 hingga 0.52521 .

Tabel 13.Tabel Frekuensi Retained Earnings to Total Assets Bank Konvensional

\begin{tabular}{|c|c|c|}
\hline Kelas & Interval & Frekuensi \\
\hline 1 & $-0.77222--0.58687$ & 2 \\
\hline 2 & $-0.58688--0.40153$ & 0 \\
\hline 3 & $-0.40154--0.21619$ & 0 \\
\hline 4 & $-0.21620--0.03085$ & 2 \\
\hline 5 & $-0.03086-0.15449$ & 13 \\
\hline 6 & $0.15450-0.33985$ & 12 \\
\hline 7 & $0.33986-0.52521$ & 40 \\
\hline
\end{tabular}

Sumber: IDX, BI data diolah 2015 oleh penulis

Penjelasan lebih lanjut akan terlihat pada hasil crosstabulation retained earnings to total assets untuk bank syariah dan bank konvensional dibawah ini:

Tabel 14. Retained Earnings to Total Assets Bank Syariah Retained Earnings to Total Assets-Kondisi Keuangan Crosstabulation Count

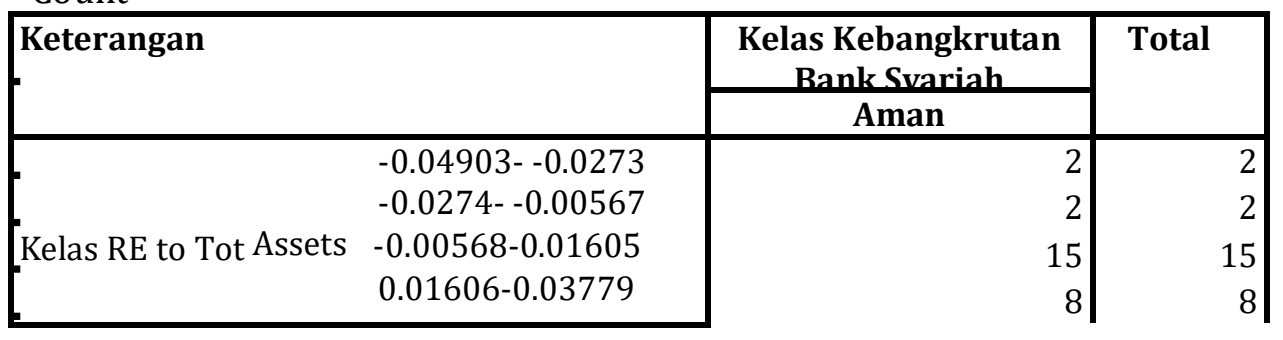




\begin{tabular}{|lr|r|r|}
\hline & $0.03780-0.05953$ & 4 & 4 \\
Total & $0.05954-0.08127$ & 2 & 2 \\
\hline
\end{tabular}

Sumber : SPSS, data diolah 2015 oleh penulis

Jika dilihat dari hasil crosstabulation untuk retained earnings to total assets perbankan syariah terlihat bahwa perbankan syariah pada rentang rasio 0.00568 hingga 0.03779 merupakan posisi aman perbankan syariah.

Tabel 15. Retained Earnings to Total Assets Bank Konvensional Retained Earnings to Total Assets-Kondisi Keuangan Crosstabulation Count

\begin{tabular}{|ll|r|r|r|}
\hline \multirow{2}{*}{ Keterangan } & \multicolumn{2}{|c|}{$\begin{array}{c}\text { Kelas Kebangkrutan Bank } \\
\text { Konvensional }\end{array}$} & \multirow{2}{*}{ Total } \\
\cline { 3 - 4 } & & Aman & Abu-abu & \\
\hline \multirow{2}{*}{ Kelas RE to Tot Assets } & $0.77222--0.58687$ & 0 & 2 & 2 \\
& $-0.21620--0.03085$ & 2 & 0 & 2 \\
Total & $0.03086-0.15449$ & 13 & 0 & 13 \\
& $0.15450-0.33985$ & 12 & 0 & 12 \\
& $0.33986-0.52521$ & 40 & 0 & 40 \\
\hline
\end{tabular}

Sumber : SPSS, data diolah 2015 oleh penulis

Sedangkan untuk hasil crosstabulation retained earnings to total assets perbankan konvensional mayoritas pada rasio 0.03086 hingga 0.52521 berada pada posisi aman. Berikut hasil uji mann whitney dalam mengetahui perbedaan retained earnings to total assets perbankan syariah dan perbankan konvensional dibawah ini:

Tabel 16. Hasil uji U Mann Whitney - Retained Earnings to Total Assets Test Statistics ${ }^{\mathrm{a}}$

\begin{tabular}{|l|r|}
\hline & $\begin{array}{r}\text { Retained Earnings to } \\
\text { total Assets }\end{array}$ \\
\cline { 2 - 2 } Mann-Whitney U & 697,000 \\
Wilcoxon W Z & 1258,000 \\
Asymp. Sig. (2-tailed) & $-3,158$ \\
&, 002 \\
\hline
\end{tabular}

a. Grouping Variable: Kelas Bank

Sumber : SPSS, data diolah 2015 oleh penulis

Dari tabel 16 terlihat bahwa nilai probabilitas Asymp. Sig. (2-tailed) $0.002<$ 0.05 , maka $\mathrm{Ha}_{2}$ diterima artinya terdapat perbedaan retained earnings to total assets antara bank syariah dan bank konvensional dalam memprediksi kebangkrutan perbankan. Penelitian ini sejalan dengan penelitian Yunita (2012) bahwa terdapat perbedaan retained earnings to total assets perbankan syariah dan konvensional. Hal ini dikarenakan penetapan bunga bank konvensional lebih tinggi dibandingkan margin bagi hasil yang ditetapkan bank syariah. Sesuai dengan tabel 11 yang telah dijelaskan sebelumnya, bahwa rata-rata bagi hasil bank syariah relatif lebih kecil dibandingkan bank konvensional. Sehingga dalam pengakumulasian laba ditahan perbankan konvensional akan terlihat lebih besar dibandingkan bank syariah, apalagi umur perbankan konvensional relatif lebih lama dibandingkan perbankan syariah. Maka dari itu, sesuai dengan hasil distribusi frekuensi dan crosstab antara bank syariah dan bank konvensional terlihat bahwa 
mayoritas perolehan nilai crosstab bank konvensional yaitu 0.52521 lebih besar dibandingkan bank syariah dengan nilai 0.01605 .

Namun demikian, walaupun nilai mayoritas dari distribusi frekuensi perbankan konvensional terlihat lebih tinggi dibandingkan perbankan syariah, tetapi nilai retained earnings to total assets perbankan konvensional lebih banyak yang mendapatkan nilai rasio negatif dibandingkan dengan perbankan syariah. Maka, dalam perolehan retained earnings to total assets terlihat bahwa perbankan syariah lebih stabil dibandingkan perbankan konvensional. Oleh karena itu, dapat disimpulkan bahwa terdapat perbedaan retained earnings to total assets perbankan syariah dan perbankan konvensional dalam memprediksi kebangkrutan perbankan.

\section{EBIT to Total Assets}

Berdasarkan tabel 17, distribusi frekuensi perbankan syariah menunjukkan bahwa bank syariah tersebar secara merata pada pada rentang rasio 0.03112 hingga 0.07083 karena perbedaan frekuensi tidak terlalu signifikan.

\section{Tabel 17. Tabel Frekuensi EBIT to Total Assets Bank Syariah}

\begin{tabular}{|c|l|c|}
\hline Kelas & Interval & Frekuensi \\
\hline 1 & $0.03112-0.03773$ & 3 \\
\hline 2 & $0.03774-0.04435$ & 7 \\
\hline 3 & $0.04436-0.05097$ & 8 \\
\hline 4 & $0.05098-0.05759$ & 9 \\
\hline 5 & $0.05760-0.06421$ & 3 \\
\hline 6 & $0.06422-0.07083$ & 3 \\
\hline
\end{tabular}

Tetapi, tabel 18 terlihat bahwa perbankan konvensional mayoritas berada pada rentang nilai 0.045225 hingga 0.079234 , karena terdapat 49 perbankan konvensional berada pada rentang nilai tersebut. Jika dibandingkan dengan hasil distribusi frekuensi perbankan syariah hanya berada pada rentang nilai rasio 0.04436 hingga 0.05759 sedangkan bank konvensional berada pada rentang nilai rasio 0.045225 hingga 0.079234 .

Tabel 18. Tabel Frekuensi EBIT to Total Assets Bank Konvensional

\begin{tabular}{|c|c|c|}
\hline Kelas & Interval & Frekuensi \\
\hline 1 & $-0.00579-0.011214$ & 1 \\
\hline 2 & $0.011215-0.028219$ & 5 \\
\hline 3 & $0.028220-0.045224$ & 6 \\
\hline 4 & $0.045225-0.062229$ & 28 \\
\hline 5 & $0.062230-0.079234$ & 21 \\
\hline 6 & $0.079235-0.096239$ & 4 \\
\hline 7 & $0.096240-0.113244$ & 4 \\
\hline
\end{tabular}

Tabel 19. EBIT to Total Assets Bank Syariah

Count

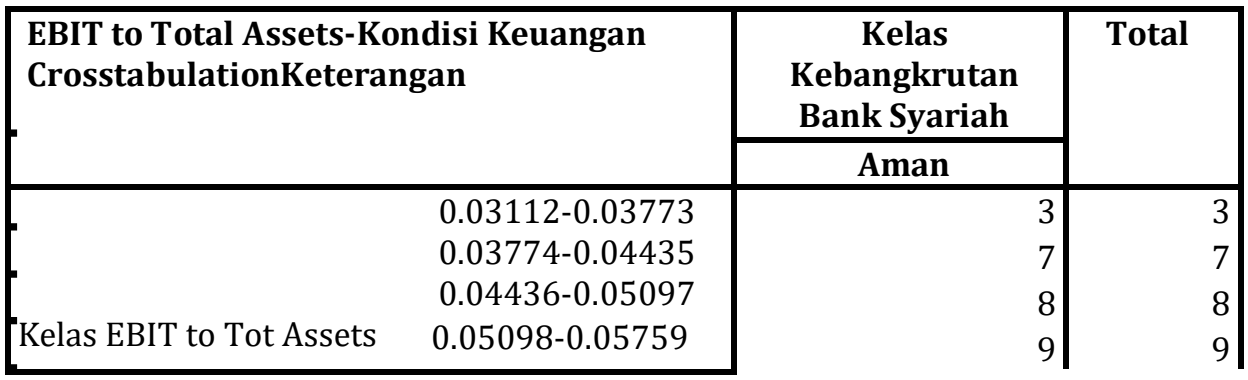




\begin{tabular}{|lr|r|r|}
\hline & $0.05760-0.06421$ & 3 & 3 \\
Total & $0.06422-0.07083$ & 3 & 3 \\
\hline
\end{tabular}

Sumber : SPSS, data diolah 2015 oleh penulis

Hasil crosstabulation untuk EBIT to total assets perbankan syariah menunjukkan bahwa perbankan syariah dengan perolehan rasio merata berada pada 0.03112 hingga 0.07083 merupakan posisi aman perbankan syariah.

Tabel 20. EBIT to Total Assets Bank Konvensional EBIT to Total Assets-Kondisi Keuangan Crosstabulation

Count

\begin{tabular}{|rr|r|r|r|}
\hline & \multicolumn{2}{|c|}{$\begin{array}{c}\text { Kelas Kebangkrutan Bank } \\
\text { Konvensional }\end{array}$} & \multirow{2}{*}{ Total } \\
\cline { 3 - 4 } & & Aman & Abu-abu & \\
\hline Kelas EBIT to Tot Assets & $0.00579-0.011214$ & 0 & 1 & 1 \\
& $0.011215-0.028219$ & 5 & 0 & 5 \\
& $0.028220-0.045224$ & 5 & 1 & 6 \\
& $0.045225-0.062229$ & 28 & 0 & 28 \\
Total & $0.062230-0.079234$ & 21 & 0 & 21 \\
& $0.079235-0.096239$ & 4 & 0 & 4 \\
& $0.096240-0.113244$ & 4 & 0 & 4 \\
\hline
\end{tabular}

Sumber : SPSS, data diolah 2015 oleh penulis

Sedangkan untuk hasil EBIT to total assets perbankan konvensional mayoritas dengan rasio 0.045225 hingga 0.079234 juga merupakan posisi aman perbankan konvensional. Berikut hail uji mann whitney dalam mengetahui perbedaan EBIT to total assets perbankan syariah dan perbankan konvensional dibawah ini:

Tabel 21. Hasil uji U Mann Whitney - EBIT to Total Assets

Test

Statistics ${ }^{\mathrm{a}}$

\begin{tabular}{|l|r|}
\hline & \multicolumn{1}{|c|}{ EBIT to Total Assets } \\
\cline { 2 - 2 } Mann-Whitney U & 732,000 \\
Wilcoxon W & 1293,000 \\
Z & $-2,908$ \\
Asymp. Sig. (2-tailed) &, 004 \\
\hline \multicolumn{2}{|c}{ a. Grouping Variable: Kelas Bank } \\
\multicolumn{2}{|c}{ Sumber : SPSS, data diolah 2015 oleh penulis }
\end{tabular}

Dari tabel 21 terlihat bahwa nilai probabilitas Asymp. Sig. (2-tailed) $0.000<$ 0.05 , maka $\mathrm{Ha}_{3}$ diterima artinya terdapat perbedaan earnings before interest and tax to total assets antara bank syariah dan bank konvensional dalam memprediksi kebangkrutan perbankan. Penelitian ini sejalan dengan penelitian Yunita (2012) bahwa terdapat perbedaan EBIT to total assets perbankan syariah dan konvensional. Sehingga dapat mengindikasikan bank syariah dan bank konvensional memiliki kemampuan yang berbeda dalam mengelola produktivitas penggunaan dana melalui kegiatan operasional maupun non operasional perusahaan untuk menghasilkan laba, disebabkan produk-produk bank syariah dan bank konvensional memiliki perbedaan.

Maka, berdasarkan distribusi frekuensi antara perbankan syariah dan perbankan konvensional terlihat bahwa perbankan syariah memiliki rentang 
rasio lebih stabil dibandingkan perbankan konvensional. Karena tidak satupun frekuensi bank syariah yang terlalu signifikan dibandingkan bank konvensional. Apalagi terdapat nilai rasio EBIT to total assets perbankan konvensional yang bernilai negatif, namun tidak terdapat satupun nilai dari EBIT to total assets perbankan syariah yang bernilai negatif. Jadi disimpulkan bahwa terdapat perbedaan EBIT to total assets bank syariah dan bank konvensional.

\section{Book Value of Equity to Total Liabilities}

Berdasarkan tabel 22 terlihat bahwa bank syariah mayoritas berada pada rasio 0.05797 hingga 0.19086 karena terbukti terdapat 25 perbankan syariah berada pada rentang nilai tersebut.

Tabel 22. Tabel Book Value of Equity to Total Liabilities Perbankan Syariah

\begin{tabular}{|c|c|c|}
\hline Kelas & Interval & Frekuensi \\
\hline 1 & $0.05797-0.19086$ & 25 \\
\hline 2 & $0.19087-0.32376$ & 5 \\
\hline 3 & $0.32377-0.45666$ & 0 \\
\hline 4 & $0.45667-0.58956$ & 0 \\
\hline 5 & $0.58957-0.72246$ & 0 \\
\hline 6 & $0.72247-0.85536$ & 3 \\
\hline \multicolumn{2}{|c|}{ Sumber: IDX BI data diolah 2015 oleh penulis } \\
\hline
\end{tabular}

Sedangkan tabel 23 menunjukkan perbankan konvensional yang dominan berada pada rasio 0.075661 hingga 0.197649 , karena terdapat 63 perbankan konvensional berada pada rentang nilai rasio tersebut.

Tabel 23 - Tabel Book Value of Equity to Total Liabilities Perbankan Konvensional

\begin{tabular}{|c|l|c|}
\hline Kelas & Interval & Frekuensi \\
\hline 1 & $0.075661-0.116323$ & 27 \\
\hline 2 & $0.116324-0.156986$ & 24 \\
\hline 3 & $0.156987-0.197649$ & 12 \\
\hline 4 & $0.197650-0.238312$ & 4 \\
\hline 5 & $0.238313-0.278975$ & 0 \\
\hline 6 & $0.278976-0.319638$ & 1 \\
\hline 7 & $0.319639-0.360301$ & 1 \\
\hline \multicolumn{2}{|l|}{ Sumber: IDX, BI data diolah 2015 oleh penulis } \\
\hline
\end{tabular}

Tabel 24. Book Value of Equity to Total Liability Bank Syariah Book Value of Equity to Total Liability-Kondisi Keuangan Crosstabulation Crosstab

Count

\begin{tabular}{|l|c|r|}
\hline Keterangan & $\begin{array}{c}\text { Kelas Kebangkrutan } \\
\text { Bank Syariah }\end{array}$ & \multirow{2}{*}{ Total } \\
& Aman & \\
\hline & & 25 \\
& 5 & 25 \\
& $0.05797-0.19086$ & 5
\end{tabular}




\begin{tabular}{|ll|r|r|}
\hline Kelas Book Value of Equity & $0.19087-0.32376$ & 3 & 3 \\
to Tot Liabilities & $0.72247-0.85536$ & 33 & 33 \\
\hline
\end{tabular}

Sumber : SPSS, data diolah 2015 oleh penulis

Berdasarkan tabel 24 diatas perbankan syariah mayoritas dengan rasio 0.05797 hingga 0.19086 merupakan posisi aman perbankan syariah.

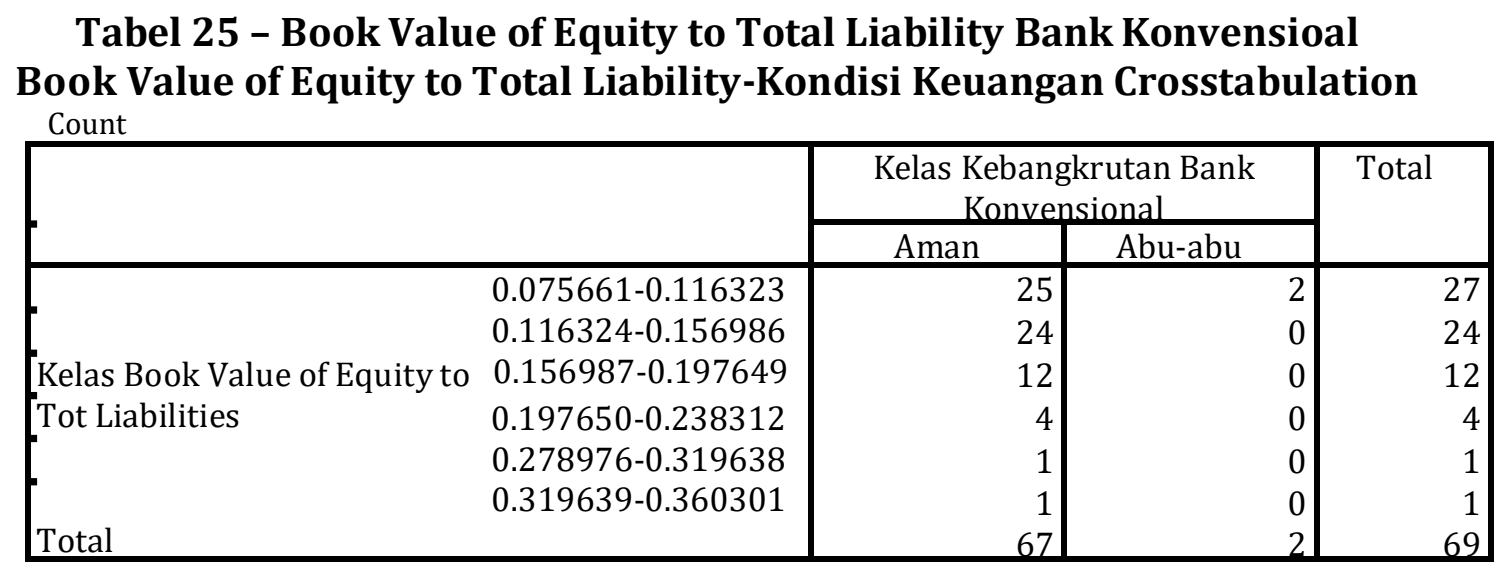

Sumber : SPSS, data diolah 2015 oleh penulis

Sedangkan untuk hasil book value of equity to total liabilities perbankan konvensional mayoritas dengan rasio 0.075661 hingga 0.197649 juga merupakan posisi aman perbankan konvensional. Namun, terdapat dua perbankan konvensional pada rentang rasio tersebut berada pada posisi abu-abu. Berikut hasil uji mann whitney dalam mengetahui apakah terdapat perbedaan book value of equity to total liabilities dibawah ini:

Tabel 26. Hasil uji U Mann Whitney - Book Value of Equity to Total Liabilities

Test Statisticsa

\begin{tabular}{|l|r|}
\hline & $\begin{array}{r}\text { Book Value of Equity to } \\
\text { Total Liabilities }\end{array}$ \\
\cline { 2 - 2 } Mann-Whitney U & 1046,000 \\
Wilcoxon W & 1607,000 \\
Z &,- 662 \\
Asymp. Sig. (2-tailed) &, 508 \\
\hline \multicolumn{2}{|c|}{ a. Grouping Variable: Kelas Bank } \\
$\quad$ Sumber : SPSS, data diolah 2015 oleh penulis
\end{tabular}

Dari tabel 26 terlihat bahwa nilai probabilitas Asymp. Sig. (2-tailed) $0.584>0.05$, maka $\mathrm{H}_{04}$ diterima artinya tidak terdapat perbedaan book value of equity to total liabilities antara bank syariah dan bank konvensional dalam memprediksi kebangkrutan perbankan. Berbeda dengan penelitian Yunita (2012) bahwa terdapat perbedaan book value of equity to book value of debt perbankan syariah dan konvensional. Hal ini dikarenakan berdasarkan nilai mayoritas dari distribusi frekuensi dan crosstab antara perbankan syariah dengan nilai 0.19086 dan perbankan konvensional 0.197649 , maka tidak terlihat perbedaan yang signifikan. Maka dapat disimpulkan dari hasil uji mann whitney tidak terdapat perbedaan book value of equity to total liabilities perbankan syariah dan perbankan konvensional dalam prediksi kebangkrutan perbankan. 


\section{KESIMPULAN}

Berdasarkan analisis rasio keuangan Altman EM Z-Score Model dilihat bahwa secara keseluruhan perbankan syariah dan perbankan konvensional Indonesia berada pada posisi aman/sehat, karena terbukti bahwa nilai rata-rata Z'-Score berada pada angka empat. Namun, dari nilai rata-rata Z"'-Score menunjukkan bahwa bank syariah lebih stabil dibandingkan bank konvensional, karena nilai Z"'-Score bank syariah yaitu 4.66 lebih besar dibandingkan nilai Z'-Score bank konvensional 4.57. Hal ini dikarenakan tidak satupun bank syariah dikategorikan berada pada posisi abu- abu bahkan bangkrut, namun terdapat satu perbankan konvensional yang berada pada posisi abu-abu.

Berikut penjelasan lebih lanjut dari hasil pengolahan data menggunakan analisis distribusi frekuensi, crosstab dan uji u mann whitney:

1. Ditemukan perbedaan working capital to total assets antara perbankan syariah dan perbankan konvensional dalam memprediksi kebangkrutan perbankan. Dikarenakan nilai tertinggi distribusi frekuensi dan crosstab perbankan syariah lebih tinggi dibandingkan perbankan konvensional, dan tidak satupun nilai rasio bank syariah yang bernilai negatif. Sehingga rasio working capital to total assets perbankan syariah lebih stabil dibandingkan perbankan konvensional.

2. Ditemukan terdapat perbedaan retained earnings to total assets antara perbankan syariah dan perbankan konvensional dalam memprediksi kebangkrutan perbankan. Hal ini dikarenakan perolehan distribusi frekuensi dan crosstab perbankan konvensional lebih banyak yang bernilai negatif dibandingkan perbankan syariah. Sehingga dari rasio retained earnings to total assets perbankan syariah lebih stabil dibandingkan perbankan konvensional dalam hal prediksi kebangkrutan perbankan.

3. Ditemukan hasil bahwa terdapat perbedaan earnings before interest and tax to total assets antara perbankan syariah dan perbankan konvensional dalam memprediksi kebangkrutan perbankan. Hal ini dikarenakan frekuensi nilai rasio EBIT to total assets perbankan syariah lebih tersebar rata atau stabil dibandingkan perbankan konvensional.

4. Ditemukan hasil bahwa tidak terdapat perbedaan book value of equity to total liabilites antara perbankan syariah dan perbankan konvensional dalam memprediksi kebangkrutan perbankan. Dikarenakan dari distribusi frekuensi perbankan syariah dan konvensional tidak mengalami perbedaan yang signifikan. Maka dari itu, dalam hal book value of equity to total liabilities tidak berbeda antara perbankan syariah dan perbankan konvensional.

Beberapa keterbatasan yaitu: (1) Penelitian ini hanya dilakukan selama 3 tahun, disebabkan keterbatasan peneliti dalam mengakses data. (2) Untuk jumlah sampel bank syariah, penulis hanya terbatas pada Bank Umum Syariah saja. Sedangkan untuk bank konvensional dalam penelitian ini hanya terbatas pada 23 perbankan konvensional yang terdaftar di Bank Indonesia, dengan mempertimbangkan faktor kelengkapan data laporan keuangan tahunan. (3) Penelitian ini hanya membandingkan dari segi rasio keuangan yang digunakan oleh pakar dunia yaitu Altman EM Z-Score Model, dikarenakan keterbatasan waktu penelitian.

\section{SARAN}

Dari hasil kesimpulan, disarankan kepada bank syariah dan konvensional secara konsisten mempertahan kinerja keuangan perbankan dan menambah inovasi 
produk mengingat perbankan syariah masih tergolong muda dalam melakukan aktivitas bisnis perbankan dibandingkan perbankan konvensional, namun perbankan konvensional harus lebih hati-hati dikarenakan kondisi keuangannya sempat beberapa memasuki posisi abu-abu, walaupun pada dasarnya hasil rasio keuangan secara rata berada ada posisi aman. Bagi peneliti selanjutnya agar memperpanjang periode penelitian sehingga terlihat gambaran yang lebih jelas dalam hal hasil prediksi dan perbandingan prediksi kebangkrutan. Sebaiknya peneliti selanjutnya mengambil bank syariah dan unit usaha syariah serta berusaha mengambil seluruh perbankan konvensional yang tidak memiliki unit usaha syariah agar dapat melihat hasil yang lebih riil dalam membandingkan prediksi kebangkrutan perbankan syariah dan konvensional. Selain membandingkan dari segi rasio keuangan yang digunakan dunia (Altman EM Z-Score), peneliti selanjutnya juga dapat membandingkan dari segi analisis kesehatan yang digunakan di Indonesia, sehingga dapat memberikan gambaran yang lebih jelas antara prediksi yang digunakan oleh dunia dan Indonesia

\section{REFERENSI}

Adnan dan Arisudhana. 2010. "Analisis Kebangkrutan Model Altman Z-Score dan Springate pada Perusahaan Industri Property". Jurnal Fakultas Ekonomi Universitas Budi Luhur Jakarta.

Altman and Heine. 2002. "Corporate Distress Prediction Models in a Turbelent Economic and Basel II Environment". Journal of Finance, September, pp 7-15

Aminah dan Sanjaya. 2014. "Analisis Kebangkrutan pada Perusahaan Perbankan di Indonesia Periode 2001-2012 (Dengan Menggunakan Model Altman Z-Score)”. Jurnal Universitas Bandar Lampung.

Angraini, Yuli Rizki. 2011. "Analisis Prediksi Kebangkrutan Perbankan berdasarkan Model Altman's Z-Score pada PT. Bank Rakyat Indonesia (Persero), Tbk”. Jurnal Akuntansi, hlm 43-49.

Antonio, Muhammad Syafii. 2001. Bank Syari'ah: Dari Teori ke Praktek. Gema Insani Press bekerja sama dengan Yayasan Tazkia Cendikia, Jakarta.

Ardiyana, Marissa. 2011. "Analisis Perbandingan Kinerja Keuangan Bank Syariah dan Bank Konvensional Sebelum, Selama dan Sesudah Krisis tahun 2008 dengan Menggunakan Metode CAMEL (Studi Kasus pada PT Bank Syariah Mandiri dan PT Bank Mandiri Tbk". Jurnal Ekonomi, hlm 16-37.

Brimantyo, Topowijono, dan Husaini. 2012. "Penerapan Analisis Altman Z- Score sebagai Salah Satu Alat untuk Mengetahui Potensi Kebangkrutan Perusahaan pada Perusahaan Telekomunikasi yang Listing di BEI Periode Tahun 20092011. Universitas Brawijaya.

Dendawijaya, Lukman. 2003. "Manajemen Perbankan". Ghalia Indonesia : Jakarta.

Endri. 2009. "Prediksi Kebangkrutan Bank untuk Menghadapi dan Mengelola Perubahan Lingkungan Bisnis: Analisis Model Altman Z-Score". Jurnal Ekonomi dan Bisnis, ISSN. 1078-9017.

Fauzi, M.Rizqi. 2013. "Analisis Perbandingan Efisiensi Bank Umum Syariah dan Bank Umum Konvensional dengan Metode Data Envelopment Analysis (DEA) (Studi Kasus BRI dan BSM pada tahun 2007-2011). Jurnal Syari'ah dan Hukum, hlm 11-20.

Ghozali, Imam. 2006. Aplikasi Analisis Multivariate dengan Program SPSS. Undip : Semarang. 
Hafifah. 2013. "Analisis Komparatif Risiko Keuangan Bank Mandiri Konvensional dan Bank Syariah Mandiri “. Jurnal Ekonomi.

Hully, Asshofiyyul. 2012. "Analisis Komparatif Tingkat Risiko Keuangan Bank Umum Konvensional dan Bank Umum Syariah Periode 2007-2010". Jurnal Ekonomi Islam hlm 1-8.

Humas Bank Indonesia. 2010. "Krisis Global dan Penyelamatan Sistem Perbankan Indonesia". Jakarta: Bank Indonesia.

Kasmir. 2004. "Bank dan Lembaga Keuangan Lainnya”. Edisi ke Delapan. Raja Grafindo Persada: Jakarta.

Kumulasari, Intan. 2012. "Analisis Perbandingan Risiko Bank Umum Syariah dengan Risiko Bank Konvensional di Indonesia (Studi Kasus pada Perusahaan perbankan Syariah dan Konvensional yang terdaftar di BI tahun 2008-2012). Jurnal Ilmu Ekonomi Islam.

Majid, Nuur Wachid A. 2015. "Mann Whitney untuk Alternatif Independent Samples T Test". Statistika.

Myrandasari, Bella. 2015. "Analisis Komparasi Stabilitas Perbankan Syariah dan Konvensional (Bank Umum Devisa Non Go Publik di Indonesia)". Jurnal Ekonomi dan Bisnis, Universitas Brawijaya.

Nurdin, Irsyad. 2012. "Peranan Analisis Metode Z- Score dalam Memprediksi Kebangkrutan suatu Perusahaan dan Kaitannya terhadap Harga Sahama (Studi pada Perusahaan Perbankan yang Go Publik Di Bursa Efek Indonesia). Jurnal Skripsi Fakultas Ekonomi Jurusan Akuntansi. Universitas Siliwangi.

Nurwati, Susi. 2014. "Analisis Komparatif Risiko Keuangan (Studi pada PT. Bank Negara Indonesia dan PT. Bank Syariah Mandiri di Indonesia)". Jurnal Ekonomi Bisnis, Universitas Muhammadiyah Surakarta.

Othman, Jaizah. 2011. "Predicting Banking Distress: A Comaparative Study Of Islamic and Conventional Banks in Malaysia". Journal of Finance, chapter 6. pp 136-155.

Praptiwi, Dyah. 2014. "Analisis Kebangkrutan Resiko Keuangan Bank Umum Konvensional dan Bank Umum Syariah". Jurnal Manajemen Fakultas Ekonomi. Hlm 2-4.

Purnamawati. 2012. "Economic Value Added (EVA) sebagai Predikator Bank Failure di Indonesia". Media Komunikasi FIS. Vol. 11. h1 - 15.

Purwanto, Rakhmat. 2011. "Analisis Perbandingan Efisiensi Bank Umum Konvensional (BUK) dan Bank Umum Syariah (BUS) di Indonesia dengan metode Data Envelopment Analysis (DEA) periode 2006-2010". Jurnal Ekonomika dan Bisnis.

Rindawati, Ema. 2007. Analisis Perbandingan Kinerja Keuangan Perbankan Syariah dengan Perbankan Konvensional. Jurnal Universitas Islam Indonesia, hlm 2427.

Salatin, Darminto dan Sudjana. 2013. "Penerapan Model Altman (Z-Score) Untuk Memprediksi Kebangkrutan pada Industri Tekstil dan Produk Tekstil yang Terdaftar di BEI Periode 2009-2011". Jurnal Administrasi Bisnis (JAB). Vol. 6 No. 2 h4.

Sariningsih, Paminto dan Nadir. 2012. “Analisis Kinerja Keuangan di Tinjau dari Rasio Likuiditas, Solvabilitas dan Rasio Profitabilitas pada CV Lembu Mada Nusantara di Samarinda". Jurnal Fakultas Ekonomi Universitas Mulawarman. 
Sindo, 20 Januari 2014. "Gaung Syariah Makin Bergema". Jurnali Koran Sindo. http://economy.okezone.com/read/2014/01/20/316/928721/gaung syariah-makin-bergema

Sugiyono. 2012. "Metode Penelitian Administrasi dengan Metode R \& D. Bandung: CV Alfabeta.

Supranto. 2008. Statistik Teori dan Aplikasi Edisi Ketujuh. Erlangga : Jakarta Umar Dan Andi. 2005. "Analisis Komparatif Resiko Keuangan Bank Prekreditan Rakyat (BPR) konvensional Dan BPR Syariah". Jurnal Manajemen \& Bisnis Sriwijaya Vol.4.

Wibowo. 2012. Sejarah Bank Syariah. Universitas Negeri Yogyakarta : Yogyakarta.

Yunita, Ira Maryana. 2013. "Pengaruh Capital Adequacy Ratio, Loan to Deposit Ratio (LDR), dan Non Performing Loan (NPL) terhadap Return on Asset (ROA) (Studi pada Perusahaan Perbankan yang Terdaftar di BEI tahun 2007-2009". Jurnal Manajemen Perbankan.

Yunita, Rizka. 2012. "Analisis Komparatif Rasio Kabangkrutan Altman antara Bank Konvensional dan Bank Syariah di Indonesia Tahun 2011". Skripsi, Jurusan Manajemen, Fakultas Ekonomi, Universitas Negeri Malang.

www.bi.go.id

www.idx.co.id 